\title{
Study the Effect of Antioxidants on Seed Quality and Enzyme Activity during Storage of Onion Seeds (Allium cepa $\mathrm{L}$. )
}

\author{
K. Varun Kumar*, Sangeeta I. Macha, N. M. Shakuntala, S. M. Prashanth and B. Kisan \\ College of Agriculture, Raichur University of Agricultural Sciences, \\ Raichur, Karnataka, India \\ *Corresponding author
}

\section{A B S T R A C T}

\begin{tabular}{l} 
Ke y w or d s \\
Allium cepa, \\
Antioxidants, \\
Ascorbic acid, \\
Alpha tocopherol, \\
Glutathione, \\
Chitosan, $\mathrm{KNO}_{3}$, \\
Polythene bag, \\
Germination, \\
Vigour \\
\hline $\begin{array}{l}\text { Article Info } \\
\text { Accepted: } \\
\text { 07 October } 2020 \\
\text { Available Online: } \\
10 \text { November } 2020\end{array}$ \\
\hline
\end{tabular}

\section{Introduction}

Onion is one of the most important bulbous vegetable cum condiment crop grown throughout the world including India. Onion belongs to the plant class Monocotyledons; order Asparagales; family Amarilidaceae; tribe Alliae and genus Allium. Cultivated onion is a cross pollination, herbaceous, biennial and diploid $(2 n=2 x=16)$ plant. Out of fifteen vegetable crops listed by the Food and Agriculture Organization (FAO) it ranks second only to tomato in terms of total annual world production. It is supposed to have its origin in Middle East countries and in the mediterranean regions. Onion has many medicinal properties. It is recommended for the persons suffering from high cholesterol, weakness, lethargy and lack of vitality. It increases the appetite and suppresses the formation of gas. Its use against sun stroke is the best remedy during summer and it is also useful in fever dropsy, cataract and chronic bronchitis of vitality (Nadkarni, 1954 and Singh et al, 2001). 
Onion is a poor storer and hence seed looses its viability very quickly. The seed quality is governed by genetic, physical and physiological status, quality of seed entering storage and storage environment (Agarwal, 1975). The seed deterioration phenomenon is interdependent among these factors other most important factor that influence the seed deterioration is lipid peroxidation of the seeds. The purpose of seed storage is to preserve planting stocks from one season to the next. In some cases, the objective of seed storage is to maintain seed quality for the largest duration possible. This approach creates a greater diversity in seed inventory and provides a guarantee of seed supply in years when acceptable seed quality and production is low. Seed deterioration during storage may be controlled through priming prior to storage (Basra et al., 2006). Seed priming is a pre-sowing treatment that involves controlled hydration of seeds, sufficient to allow pre-germinative metabolic events to take place and to restrict radicle protrusion through the seed coat (Heydecker et al, 1973). Autoxidation of lipids and increase in the content of free fatty acids during storage period are the main reasons for rapid deterioration. Oxidation is a chemical reaction that transfers electron or hydrogen from a substance to an oxidizing agent. In turn, these radicals can start a chain reaction which occurs in a cell and cause damage or death to the cell.

Antioxidant is a molecule that terminates these chain reaction by removing free radical intermediates and inhibit other oxidation reactions. These deleterious reactions are controlled in part by antioxidants that eliminate ROS and scavenge free radicals. Various abiotic stresses lead to the over production of reactive oxygen species (ROS) in plants and seed which are highly reactive and toxic and cause damage to proteins, lipids, carbohydrates and DNA which ultimately results in oxidative stress.
Seed priming with antioxidants can help the seeds to retain their viability for much longer, as the major cause of seed deterioration in onion seed is the production of ROS which is produced as the age of seed increases leading seeds to loose viability. Therefore use of antioxidants may have potential to be cost effective mechanism for prolonging the storage life.

\section{Materials and Methods}

The experiment was conducted at Department of Seed Science and Technology, College of Agriculture, Raichur. The experiment consists of Arka Kalyan onion seeds. The experiment was conducted in completely randomised block design with four replications. The seeds were primed with $\mathrm{KNO}_{3}(2 \%)$, ascorbic acid (50mg/L), alpha tocopherol (0.5\%), glutathione $(0.05 \%)$, combination of ascorbic acid, alpha tocopherol and glutathione $(\mathrm{A}+\mathrm{T}+\mathrm{G})(0.5 \%+0.3 \%+0.05 \%)$ and chitosan $(0.25 \%)$. The primed seeds were dried to the optimum moisture content and packed in polythene bag (700 guage), heat sealed and stored under ambient condition in the laboratory of Department of Seed Science and Technology. The observation on physiological parameters were taken monthly on moisture content, test weight, germination (\%), speed of germination, shoot length, root length, seedling dry weight and seedling vigour index. The observations on biochemical parameters were take bimonthly on electrical conductivity, dehydrogenase enzyme activity and alpha amylase activity. The antioxidant enzyme activities like peroxidase activity and superoxide dismutase enzyme activity were taken at initial month of storage and at the end of the storage period. The laboratory germination test was conducted as per ISTA procedure by adopting rolled towel paper method (Anon., 1996). Vigour index was calculated by using the formula, VI = Germination per cent $(\%) \mathrm{x}$ 
Total seedling length (cm) (Abdul-Baki and Anderson, 1973). Ten normal seedlings used for measuring seedling length were dried in a hot air oven at $70 \pm 1{ }^{0} \mathrm{C}$ temperature for 24 hours. Then the seedlings were cooled in desiccators for 30 minutes and weight was recorded and expressed in milli grams (Evans and Bhatt, 1977).

\section{Results and Discussion}

Seeds primed with antioxidants, $\mathrm{KNO}_{3}$ and chitosan differed significantly during onion seed storage. All the treatments are significantly superior over untreated control. In general as the storage period advanced, the seed quality parameters gradually declined. Among the treatments, combination of ascorbic acid, alpha tocopherol and glutathione $(\mathrm{A}+\mathrm{T}+\mathrm{G}) \quad(0.5 \%+0.3 \%+0.05 \%)$ $\left(\mathrm{T}_{6}\right)$ recorded significantly highest germination, speed of germination, seedling dry weight and seedling vigour index (95.00\%, 34.28, $22.05 \mathrm{mg}$ and 1568, respectively) which was on par with ascorbic acid at $50 \mathrm{mg}\left(\mathrm{T}_{3}\right)$ in germination, speed of germination, seedling dry weight and seedling vigour index $(94.25 \%, 34.14,20.95 \mathrm{mg}$ and 1510 , respectively) whereas, the lowest was recorded in control $\left(\mathrm{T}_{1}\right)(90.25 \% 29.19,18.32$ $\mathrm{mg}$ and 1239, respectively) at the initial month of storage. At the end of storage period seed primed with combination of $A+T+G$ (T6) maintained significantly the highest germination, speed of germination, seedling dry weight and seedling vigour index (79.50\%, 18.16, $15.78 \mathrm{mg}$ and 1068, respectively) which was on par with ascorbic acid at $50 \mathrm{mg}$ (T3) $(77.75 \%, 17.98,15.59 \mathrm{mg}$ and 1012, respectively), whereas untreated control recorded lowest of all these seed attributes throughout storage period. These findings are in accordance with Draganic and Slavoljub (2012) in sunflower seed who have reported the enhancement in the seed germination by seed priming with the combination of ascorbic acid, alpha tocopherol and glutathione $(\mathrm{A}+\mathrm{T}+\mathrm{G})$ as compared to the control. Similar results were obtained by Ramya (2015) in soybean seed treated with ascorbic acid (300 ppm) resulted in the highest germination percentage at the end of 10 months of storage.

Among the biochemical parameters, $\mathrm{T}_{6}$ maintained the lowest electrical conductivity (EC) and highest dehydrogenase enzyme activity and alpha amylase activity (0.382 $\mathrm{dSm}^{-1}, 1.270 \mathrm{OD}$ value and $25.13 \mathrm{~mm}$, respectively) and was on par with $\mathrm{T}_{3}$ in electrical conductivity and alpha amylase activity $\left(0.383 \mathrm{dSm}^{-1}\right.$ and $25.06 \mathrm{~mm}$, respectively). Highest electrical conductivity and lowest dehydrogenase and alpha amylase enzyme activities were observed in control $\left(0.433 \mathrm{dSm}^{-1}, 1.046 \mathrm{OD}\right.$ value and $22.53 \mathrm{~mm}$, respectively) during the initial month of storage. At the end of the storage period, $\mathrm{T}_{6}$ recorded lowest electrical conductivity and highest dehydrogenase enzyme activity and alpha amylase activity $\left(0.556 \mathrm{dSm}^{-1}, 0.831\right.$ OD value and $17.56 \mathrm{~mm}$, respectively) which was on par with $T_{3}$ in alpha amylase activity $(17.14 \mathrm{~mm})$, while control recorded highest electrical conductivity and lowest dehydrogenase enzyme activity and alpha amylase activity $\left(0.755 \mathrm{dSm}^{-1}, 0.617 \mathrm{OD}\right.$ value and $13.69 \mathrm{~mm}$, respectively). Moori and Hamid (2017) showed that maximum leakage of electrolytes from seeds occurred when they had not been primed. However, when they were primed with the combination of $A+T+G$ and ascorbic acid, metabolites leakage reached its minimum level.

These results are similar to the finding of Afzal et al., (2006) who showed that maximum EC of seed leachates was recorded in untreated seeds. All the seed treatments resulted in lower EC of seed leachates compared with check. Minimum EC of seed leachates was noted in seeds subjected to 50 
ppm ascorbic acid. As the storage period increased the enzyme activity also decreased. This may be due to the reduction in the utilization of glucose by the seeds. This type results also observed by Ramya (2015) in soyabean seeds stored for 12 months.

Table.1 Effect of seed priming with antioxidants on germination per cent of onion seeds during storage

\begin{tabular}{|c|c|c|c|c|c|c|c|c|c|c|}
\hline \multirow[t]{2}{*}{ Treatment } & \multicolumn{10}{|c|}{ Months after storage } \\
\hline & 1 & 2 & 3 & 4 & 5 & 6 & 7 & 8 & 9 & 10 \\
\hline $\mathbf{T}_{1}$ - Control & 90.25 & 90.00 & 89.25 & 88.00 & 86.25 & 83.25 & 79.25 & 76.75 & 72.50 & 68.50 \\
\hline $\mathrm{T}_{2}$ - Priming with $\mathrm{KNO}_{3}(2 \%)$ & 92.75 & 92.25 & 91.50 & 90.25 & 89.75 & 87.00 & 84.25 & 82.25 & 78.75 & 73.25 \\
\hline $\begin{array}{l}\text { T }_{3-} \text { Priming with Ascorbic acid } \\
\text { (A)- }(50 \mathrm{mg})\end{array}$ & 94.25 & 93.75 & 93.00 & 91.75 & 90.50 & 88.50 & 86.25 & 83.75 & 80.25 & 77.75 \\
\hline $\begin{array}{l}\text { T }_{4} \text { - Priming with Alpha } \\
\text { Tocopherol (T)-(0.5\%) }\end{array}$ & 93.25 & 93.00 & 91.75 & 90.25 & 89.50 & 87.50 & 85.75 & 80.75 & 79.25 & 75.50 \\
\hline $\begin{array}{l}\text { T }_{5-\text { Priming with Glutathione }} \\
(\mathbf{G})-(0.05 \%)\end{array}$ & 93.75 & 93.50 & 92.25 & 90.75 & 89.25 & 88.00 & 83.75 & 83.75 & 77.25 & 76.50 \\
\hline $\begin{array}{l}T_{6-} \text { Priming with A+T+G } \\
(0.5 \%+0.3 \%+0.05 \%)\end{array}$ & 95.00 & 94.50 & 93.75 & 92.50 & 92.00 & 90.50 & 87.50 & 85.50 & 82.75 & 79.50 \\
\hline $\begin{array}{l}\text { T }_{7-} \text { Priming with Chitosan } \\
(0.25 \%)\end{array}$ & 91.75 & 91.50 & 91.00 & 89.75 & 88.50 & 85.75 & 82.50 & 80.25 & 77.50 & 72.25 \\
\hline Mean & 93.00 & 92.64 & 91.79 & 90.46 & 89.39 & 87.21 & 84.18 & 81.86 & 78.32 & 74.75 \\
\hline 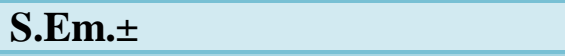 & 0.66 & 0.68 & 0.79 & 0.76 & 0.84 & 0.69 & 0.74 & 0.75 & 0.69 & 0.74 \\
\hline CD@1\% & 2.64 & 2.71 & 3.15 & 3.05 & 3.36 & 2.78 & 2.96 & 3.01 & 2.75 & 2.97 \\
\hline
\end{tabular}

Table. 2 Effect of seed priming with antioxidants on speed of germination of onion seeds during storage

\begin{tabular}{|c|c|c|c|c|c|c|c|c|c|c|}
\hline \multirow[t]{2}{*}{ Treatment } & \multicolumn{10}{|c|}{ Months after storage } \\
\hline & 1 & 2 & 3 & 4 & 5 & 6 & 7 & 8 & 9 & 10 \\
\hline $\mathbf{T}_{1-}$ Control & 29.19 & 28.10 & 26.20 & 24.13 & 23.12 & 20.52 & 17.41 & 15.66 & 14.49 & 13.12 \\
\hline $\mathrm{T}_{2}$ - Priming with $\mathrm{KNO}_{3}(2 \%)$ & 31.92 & 31.06 & 28.91 & 27.07 & 26.65 & 24.40 & 20.26 & 18.58 & 17.37 & 15.96 \\
\hline $\begin{array}{l}\text { T }_{3} \text { - Priming with Ascorbic acid } \\
\text { (A)-(50mg) }\end{array}$ & 34.14 & 33.12 & 31.14 & 29.23 & 28.64 & 26.69 & 22.51 & 20.64 & 18.72 & 17.98 \\
\hline $\begin{array}{l}\text { T}_{4} \text { - Priming with Alpha } \\
\text { Tocopherol (T)-(0.5\%) }\end{array}$ & 32.23 & 31.31 & 29.19 & 27.34 & 27.24 & 25.62 & 21.41 & 19.80 & 7.66 & 16.31 \\
\hline $\begin{array}{l}T_{5} \text { - Priming with Glutathione } \\
(\mathbf{G})-(0.05 \%)\end{array}$ & 33.90 & 32.89 & 30.83 & 28.90 & 27.96 & 24.32 & 21.97 & 20.47 & 19.31 & 17.20 \\
\hline $\begin{array}{l}\text { T }_{6} \text { - Priming with A+T+G } \\
(0.5 \%+0.3 \%+0.05 \%)\end{array}$ & 34.28 & 33.34 & 31.26 & 30.87 & 28.70 & 25.48 & 22.96 & 21.20 & 19.61 & 18.16 \\
\hline $\begin{array}{l}\mathbf{T}_{7^{-}} \text {Priming with Chitosan } \\
(0.25 \%)\end{array}$ & 31.79 & 30.90 & 28.76 & 26.80 & 26.20 & 23.71 & 20.12 & 18.31 & 17.18 & 15.05 \\
\hline Mean & 32.49 & 31.53 & 29.47 & 27.76 & 26.93 & 24.39 & 20.95 & 19.24 & 17.76 & 16.25 \\
\hline S.Em. \pm & 0.09 & 0.08 & 0.14 & 0.07 & 0.10 & 0.06 & 0.07 & 0.06 & 0.06 & 0.05 \\
\hline CD@1\% & 0.38 & 0.31 & 0.57 & 0.26 & 0.39 & 0.25 & 0.26 & 0.24 & 0.22 & 0.20 \\
\hline
\end{tabular}


Table.3 Effect of seed priming with antioxidants on seedling dry weight $(\mathrm{mg})$ of onion seeds during storage

\begin{tabular}{|c|c|c|c|c|c|c|c|c|c|c|}
\hline \multirow[t]{2}{*}{ Treatment } & \multicolumn{10}{|c|}{ Months after storage } \\
\hline & 1 & 2 & 3 & 4 & 5 & 6 & 7 & 8 & 9 & 10 \\
\hline $\mathbf{T}_{1}$ - Control & 18.32 & 18.02 & 17.61 & 16.86 & 15.66 & 13.80 & 12.33 & 11.31 & 10.60 & 9.76 \\
\hline $\mathrm{T}_{2^{-}}$Priming with $\mathrm{KNO}_{3}(2 \%)$ & 19.07 & 18.91 & 18.72 & 18.47 & 18.24 & 17.35 & 16.74 & 15.33 & 13.92 & 13.27 \\
\hline $\begin{array}{l}T_{3} \text { - Priming with Ascorbic acid } \\
\text { (A)-(50mg) }\end{array}$ & 20.95 & 20.63 & 20.12 & 19.72 & 19.45 & 18.99 & 18.04 & 16.84 & 16.03 & 15.59 \\
\hline $\begin{array}{l}T_{4} \text { - Priming with Alpha } \\
\text { Tocopherol (T)-(0.5\%) }\end{array}$ & 33 & 17 & 19.02 & 18.79 & 8.60 & 17.96 & 16.56 & 5.44 & 14.43 & 3.96 \\
\hline $\begin{array}{l}T_{5^{-}} \text {Priming with Glutathione } \\
(\mathbf{G})-(0.05 \%)\end{array}$ & 19.95 & 19.72 & 19.47 & 19.09 & 18.86 & 18.03 & 17.54 & 15.73 & 15.02 & 14.15 \\
\hline $\begin{array}{l}\mathrm{T}_{6^{-}} \text {Priming with } \mathrm{A}+\mathrm{T}+\mathrm{G} \\
(0.5 \%+0.3 \%+0.05 \%)\end{array}$ & 22.05 & 21.67 & 21.18 & 20.77 & 20.12 & 19.20 & 18.33 & 16.92 & 16.15 & 15.78 \\
\hline $\begin{array}{l}T_{7} \text { - Priming with Chitosan } \\
(0.25 \%)\end{array}$ & 18.75 & 18.23 & 17.88 & 17.51 & 16.91 & 15.92 & 15.35 & 14.24 & 13.59 & 12.74 \\
\hline Mean & 19.78 & 19.48 & 19.14 & 18.74 & 18.27 & 17.32 & 16.41 & 15.12 & 14.25 & 13.60 \\
\hline S.Em.. & 0.18 & 0.347 & 0.323 & 0.377 & 0.072 & 0.06 & 0.136 & 0.049 & 0.074 & 0.052 \\
\hline CD@1\% & 0.721 & 1.39 & 1.294 & 1.512 & 0.291 & 0.24 & 0.545 & 0.197 & 0.298 & 0.208 \\
\hline
\end{tabular}

Table.4 Effect of seed priming with antioxidants on seedling vigour index of onion seeds during storage

\begin{tabular}{|c|c|c|c|c|c|c|c|c|c|c|}
\hline \multirow[t]{2}{*}{ Treatment } & \multicolumn{10}{|c|}{ Months after storage } \\
\hline & 1 & 2 & 3 & 4 & 5 & 6 & 7 & 8 & 9 & 10 \\
\hline$T_{1}-$ Control & 1239 & 1221 & 1190 & 1141 & 1098 & 1032 & 929 & 857 & 755 & 658 \\
\hline $\mathrm{T}_{2}$ - Priming with $\mathrm{KNO}_{3}(2 \%)$ & 1370 & 1352 & 1320 & 1287 & 1329 & 1186 & 1111 & 1046 & 955 & 857 \\
\hline $\begin{array}{l}T_{3} \text { - Priming with Ascorbic acid } \\
\text { (A)-(50mg) }\end{array}$ & 1510 & 1482 & 1450 & 1414 & 1379 & 1317 & 1239 & 1148 & 1074 & 1012 \\
\hline $\begin{array}{l}\mathbf{T}_{4} \text { - Priming with Alpha } \\
\text { Tocopherol (T)-(0.5\%) }\end{array}$ & 1402 & 1389 & 1343 & 1303 & 1272 & 1221 & 1150 & 1046 & 991 & 914 \\
\hline $\begin{array}{l}T_{5}-\text { Priming with Glutathione } \\
(\mathbf{G})-(0.05 \%)\end{array}$ & 1446 & 1417 & 1387 & 1355 & 1322 & 1269 & 1165 & 1137 & 1004 & 955 \\
\hline $\begin{array}{l}T_{6} \text { - Priming with } A+T+G \\
(0.5 \%+0.3 \%+0.05 \%)\end{array}$ & 1568 & 1540 & 1503 & 1469 & 1439 & 1382 & 1286 & 1230 & 1153 & 1068 \\
\hline $\begin{array}{l}\mathbf{T}_{7} \text { - Priming with Chitosan } \\
(0.25 \%)\end{array}$ & 1313 & 1295 & 1269 & 1232 & 1201 & 1134 & 1045 & 973 & 897 & 797 \\
\hline Mean & 1407 & 1385 & 1352 & 1314 & 1292 & 1220 & 1132 & 1062 & 976 & 894 \\
\hline S.Em. \pm & 11.70 & 11.49 & 15.77 & 12.38 & 12.92 & 12.51 & 10.54 & 10.45 & 9.17 & 10.30 \\
\hline CD@1\% & 46.85 & 46.01 & 63.14 & 49.57 & 51.73 & 50.08 & 42.22 & 41.85 & 36.73 & 58.26 \\
\hline
\end{tabular}


Table.5 Effect of seed priming with antioxidants on electrical conductivity $\left(\mathrm{dS} \mathrm{m}^{-1}\right)$ of onion seeds during storage

\begin{tabular}{|c|c|c|c|c|c|c|}
\hline \multirow[t]{2}{*}{ Treatment } & \multicolumn{6}{|c|}{ Months after storage } \\
\hline & Initial & 2 & 4 & 6 & 8 & 10 \\
\hline $\mathbf{T}_{1^{-}}$Control & 0.433 & 0.479 & 0.595 & 0.669 & 0.714 & 0.755 \\
\hline $\mathrm{T}_{2}$ - Priming with $\mathrm{KNO}_{3}(2 \%)$ & 0.395 & 0.439 & 0.506 & 0.560 & 0.622 & 0.674 \\
\hline $\mathbf{T}_{3^{-}}$Priming with Ascorbic acid (A)-(50mg) & 0.383 & 0.395 & 0.465 & 0.509 & 0.587 & 0.614 \\
\hline $\mathbf{T}_{4}$ - Priming with Alpha Tocopherol (T)-(0.5\%) & 0.392 & 0.428 & 0.499 & 0.553 & 0.617 & 0.660 \\
\hline$T_{5^{-}}$Priming with Glutathione (G)-(0.05\%) & 0.389 & 0.420 & 0.484 & 0.531 & 0.593 & 0.647 \\
\hline $\mathrm{T}_{6}-$ Priming with $\mathrm{A}+\mathrm{T}+\mathrm{G}(0.5 \%+0.3 \%+0.05 \%)$ & 0.382 & 0.383 & 0.444 & 0.448 & 0.502 & 0.556 \\
\hline $\mathrm{T}_{7}$ - Priming with Chitosan $(0.25 \%)$ & 0.400 & 0.456 & 0.526 & 0.568 & 0.634 & 0.689 \\
\hline Mean & 0.396 & 0.429 & 0.502 & 0.549 & 0.610 & 0.657 \\
\hline S.Em. \pm & 0.001 & 0.002 & 0.001 & 0.002 & 0.001 & 0.001 \\
\hline CD@1\% & 0.005 & 0.006 & 0.006 & 0.008 & 0.002 & 0.005 \\
\hline
\end{tabular}

Table.6 Effect of seed priming with antioxidants on dehydrogenase enzyme activity (OD value) of onion seeds during storage

\begin{tabular}{|c|c|c|c|c|c|c|}
\hline \multirow[t]{2}{*}{ Treatment } & \multicolumn{6}{|c|}{ Months after storage } \\
\hline & Initial & 2 & 4 & 6 & 8 & 10 \\
\hline $\mathbf{T}_{1}$ - Control & 1.046 & 1.022 & 0.939 & 0.785 & 0.694 & 0.617 \\
\hline $\mathrm{T}_{2}-$ Priming with $\mathrm{KNO}_{3}(2 \%)$ & 1.149 & 1.115 & 1.026 & 0.879 & 0.745 & 0.704 \\
\hline $\mathbf{T}_{3^{-}}$Priming with Ascorbic acid (A)-(50mg) & 1.251 & 1.196 & 1.130 & 0.996 & 0.917 & 0.786 \\
\hline $\mathrm{T}_{4}$ - Priming with Alpha Tocopherol (T)-(0.5\%) & 1.176 & 1.084 & 0.897 & 0.834 & 0.788 & 0.707 \\
\hline $\mathrm{T}_{5}$ - Priming with Glutathione $(\mathrm{G})-(0.05 \%)$ & 1.226 & 1.178 & 1.091 & 0.959 & 0.795 & 0.762 \\
\hline $\mathrm{T}_{6}-$ Priming with $\mathrm{A}+\mathrm{T}+\mathrm{G}(0.5 \%+0.3 \%+0.05 \%)$ & 1.270 & 1.216 & 1.157 & 1.088 & 0.894 & 0.831 \\
\hline $\mathbf{T}_{7}$ - Priming with Chitosan $(0.25 \%)$ & 1.114 & 1.076 & 0.987 & 0.918 & 0.734 & 0.677 \\
\hline Mean & 1.176 & 1.126 & 1.032 & 0.922 & 0.796 & 0.726 \\
\hline S.Em. \pm & 0.002 & 0.002 & 0.003 & 0.003 & 0.002 & 0.003 \\
\hline CD@1\% & 0.009 & 0.007 & 0.014 & 0.014 & 0.008 & 0.012 \\
\hline
\end{tabular}

Table.7 Effect of seed priming with antioxidants on alpha-amylase (mm) of onion seeds during storage

\begin{tabular}{|c|c|c|c|c|c|c|}
\hline \multirow[t]{2}{*}{ Treatment } & \multicolumn{6}{|c|}{ Months after storage } \\
\hline & Initial & 2 & 4 & 6 & 8 & 10 \\
\hline $\mathbf{T}_{1}$ - Control & 22.53 & 21.78 & 19.61 & 16.85 & 14.77 & 13.69 \\
\hline $\mathrm{T}_{2}$ - Priming with $\mathrm{KNO}_{3}(2 \%)$ & 23.87 & 23.55 & 21.16 & 19.95 & 17.28 & 16.36 \\
\hline $\mathbf{T}_{3^{-}}$Priming with Ascorbic acid (A)-(50mg) & 25.06 & 24.65 & 21.85 & 20.83 & 18.71 & 17.14 \\
\hline $\mathrm{T}_{4}$ - Priming with Alpha Tocopherol (T)-(0.5\%) & 24.32 & 24.00 & 21.37 & 20.18 & 17.81 & 16.88 \\
\hline$T_{5}-$ Priming with Glutathione $(G)-(0.05 \%)$ & 24.80 & 24.20 & 23.48 & 20.44 & 18.39 & 17.02 \\
\hline $\mathrm{T}_{6}-$ Priming with $\mathrm{A}+\mathrm{T}+\mathrm{G}(0.5 \%+0.3 \%+0.05 \%)$ & 25.13 & 24.32 & 22.69 & 21.13 & 19.37 & 17.56 \\
\hline $\mathrm{T}_{7}$ - Priming with Chitosan $(0.25 \%)$ & 23.20 & 22.40 & 20.81 & 17.89 & 16.79 & 15.55 \\
\hline Mean & 24.13 & 23.56 & 21.57 & 19.61 & 17.59 & 16.31 \\
\hline S.Em. \pm & 0.03 & 0.02 & 0.03 & 0.04 & 0.03 & 0.04 \\
\hline CD@1\% & 0.11 & 0.06 & 0.11 & 0.18 & 0.14 & 0.16 \\
\hline
\end{tabular}


Table.8 Effect of seed priming with antioxidants on superoxide dismutase (IU/g F wt) and peroxidase $\left(\mathrm{n} \mathrm{mol} \mathrm{g}^{-1}\right)$ of onion seeds during storage

\begin{tabular}{|c|c|c|c|c|}
\hline \multirow[t]{2}{*}{ Treatment } & \multicolumn{2}{|c|}{ SOD } & \multicolumn{2}{|c|}{ POD } \\
\hline & $\begin{array}{l}\text { Initial } \\
\text { month }\end{array}$ & $\begin{array}{c}\text { Final } \\
\text { month }\end{array}$ & $\begin{array}{l}\text { Initial } \\
\text { month }\end{array}$ & $\begin{array}{l}\text { Final } \\
\text { month }\end{array}$ \\
\hline $\mathbf{T}_{1^{-}}$Control & 1.71 & 0.62 & 6.26 & 3.08 \\
\hline $\mathrm{T}_{2^{-}}$Priming with $\mathrm{KNO}_{3}(2 \%)$ & 1.87 & 0.91 & 6.27 & 3.96 \\
\hline$T_{3^{-}}$Priming with Ascorbic acid (A)-(50mg) & 2.01 & 1.12 & 6.30 & 4.28 \\
\hline $\mathrm{T}_{4}$ - Priming with Alpha Tocopherol (T)-(0.5\%) & 1.91 & 0.98 & 6.29 & 4.13 \\
\hline $\mathrm{T}_{5}$ - Priming with Glutathione $(\mathrm{G})-(0.05 \%)$ & 1.95 & 1.07 & 6.29 & 4.22 \\
\hline $\mathrm{T}_{6}-$ Priming with $\mathrm{A}+\mathrm{T}+\mathrm{G}(0.5 \%+0.3 \%+0.05 \%)$ & 2.03 & 1.16 & 6.32 & 4.53 \\
\hline$T_{7}$ Priming with Chitosan $(0.25 \%)$ & 1.77 & 0.84 & 6.26 & 3.72 \\
\hline Mean & 1.89 & 0.96 & 6.28 & 3.99 \\
\hline S.Em. \pm & 0.02 & 0.06 & 0.10 & 0.06 \\
\hline CD@1\% & 0.03 & 0.12 & NS & 0.26 \\
\hline
\end{tabular}

NS- Non significant

Among the treatments, Priming with $\mathrm{A}+\mathrm{T}+\mathrm{G}$ $(0.5 \%+0.3 \%+0.05 \%) \quad\left(\mathrm{T}_{6}\right) \quad$ maintained significantly highest superoxide dismutase (SOD) and peroxidase enzyme activity (POD) at initial $(2.03 \mathrm{IU} / \mathrm{g} \mathrm{F}$ wt and $6.32 \mathrm{n} \mathrm{mol} / \mathrm{g})$ and at the end of storage period (1.16 IU/g F wt and $4.53 \mathrm{n} \mathrm{mol} / \mathrm{g}$ ). However significantly lowest superoxide dismutase and peroxidase enzyme activity were observed in control at initial (1.71 IU/g F wt and $6.26 \mathrm{n} \mathrm{mol} / \mathrm{g}$ respectively) and at the end of storage period $(0.62 \mathrm{IU} / \mathrm{g} \quad \mathrm{F} \quad \mathrm{wt}$ and $3.08 \mathrm{n} \mathrm{mol} / \mathrm{g}$ respectively). Moori and Esivand (2017) showed that seed priming with the ascorbic acid significantly increased the activity of SOD and POD in the accelerated aged wheat seeds more than that of the untreated control. Ahmed et al., (2012) revealed that seed priming induced significantly increased POD activity but maximum of POD activity of 5.73 and 5.65 units $\mathrm{mg}^{-1}$ of protein were observed when seeds were pre-soaked with ascorbic acid (20 and $40 \mathrm{mg} \mathrm{L}^{-1}$ ), respectively. Control gave the lowest POD activity (4.39 units mg1 of protein).

These findings are also supported by Ahmed et al., (2012) showed that the seed priming with ascorbic acid, salicylic acid and hydrogen peroxide enhanced SOD activity. Higher SOD activity in seeds under chilling stress suggests a more efficient scavenging system which may result in better protection against ROS during stress.

The results of the germination per cent, speed of germination, seedling dry weight, seedling vigour index, electrical conductivity, dehydrogenase enzyme activity, alpha amylase enzyme activities, superoxide dismutase and peroxidase enzyme activity of onion seeds during the months of storage as influenced by seed priming treatments are presented in Tables 1 to 8 .

\section{References}

Abdul-Baki, A. A., Anderson, J. D., 1973, Vigour determination in soybean by multiple criteria. Crop Sci., 13:630633.

Afzal, I., Basra, S. M., Farooq, M. and Nawaz, A., 2006, Alleviation of salinity stress in spring wheat by hormonal priming with ABA, salicylic acid and ascorbic acid. Int. J. Agric. Biol., 8(1): 23-28.

Agarwal, P. K., 1975, Problems of seed 
viability in soybean during storage. Seed Tech. News., 5: 14-17.

Ahmad, I., Khaliq, T., Ahmad, A., Basra, S. M., Hasnain, Z. and Ali, A., 2012, Effect of seed priming with ascorbic acid, salicylic acid and hydrogen peroxide on emergence, vigor and antioxidant activities of maize. African J. Biotechnol., 11(5): 1127-1132.

Anonymous. 1996, International rules for seed testing. Seed Sci. \& Technol. 29:1-335.

Basra, S. M. A., Farooq, M., Wahid, A. and Khan, M. B., 2006, Rice seed invigoration by hormonal and vitamin priming. Seed Sci. Technol., 34(3): 753-758.

Draganic, I. and Slavoljub, 2012, Seed priming with antioxidants improves sunflower seed germination and seedling growth under unfavourable germination condition. Turk. J. Agric., 36: 421-428.

Evans, L.E., Bhat, G.M., 1977, A nondestructive technique for measuring seedling vigour in wheat. Canadian $\mathrm{J}$. of Plant Sci., 57:983-985.

Heydecker, W., Higgis, J. and Gulliver, R. L., 1973, Accelerated germination by osmotic treatments. Nature, 246: 4244.

Ramya, D., 2015, Seed storability enhancement studies in soyabean (Glycine max L.). M.Sc.(Agri) Thesis, Univ. Agric. Sci., Telangana, India.

Moori, S. and Eisvand, H.R., 2017, Plant growth regulators and ascorbic acid effects on physiological quality of wheat seedlings obtained from deteriorated seeds. Pak. J. Bot, 49(5), pp.1811-1819.

Nadkarni, K. M., 1954, Allium cepa L. and Allium sativum L. In: Indian materia medica. 3rd edn. (Part-I) (hiranik, M.V. and Bhatkal, G.R. Eds) Popular Book Depot. Bombay, 63.

Singh, J., Kalloo, G. and Singh, K.P., 2001, Vegetable crops: Nutritional security. Technical Bulletin 6 IIVR, BHU Varanasi, India.

\section{How to cite this article:}

Varun Kumar, K., Sangeeta I. Macha, N. M. Shakuntala, S. M. Prashanth and Kisan, B. 2020. Study the Effect of Antioxidants on Seed Quality and Enzyme Activity during Storage of Onion Seeds (Allium cepa L.). Int.J.Curr.Microbiol.App.Sci. 9(11): 715-722. doi: https://doi.org/10.20546/ijcmas.2020.911.086 